\title{
Prognostic significance of EpCAM expression in human esophageal cancer
}

\author{
HITOSHI KIMURA, HIROYUKI KATO, AHMAD FARIED, MAKOTO SOHDA, \\ MASANOBU NAKAJIMA, YASUYUKI FUKAI, TATSUYA MIYAZAKI, \\ NORIHIRO MASUDA, MINORU FUKUCHI and HIROYUKI KUWANO
}

Depertment of General Surgical Science, Gunma University, Graduate School of Medicine, Maebashi, Japan

Received July 27, 2006; Accepted September 20, 2006

\begin{abstract}
EpCAM is a $40-\mathrm{kDa}$ epithelial transmembrane glycoprotein that has a well-known role in $\mathrm{Ca}^{2+}$-independent homophilic cell-cell adhesion. Recently, correlations between EpCAM expression and clinicopathological features have been investigated in various cancers. We examined EpCAM expression in surgical specimens from esophageal cancer patients $(n=138)$, using real-time RT-PCR, immunohistochemistry and ELISA. The mean expression level of EpCAM mRNA in tumor tissues was significantly higher than that in corresponding normal tissues $(\mathrm{P}<0.0001)$. Immunohistochemically, positive staining for EpCAM was found in 135 (97.8\%) of the 138 primary tumor specimens. EpCAM expression was correlated with tumor depth $(\mathrm{P}=0.0005)$, stage $(\mathrm{P}=0.0037)$, blood-vessel invasion $(\mathrm{P}=0.0397)$ and infiltrative growth pattern $(\mathrm{P}=0.0015)$. The survival rates of patients with tumors with high EpCAM expression was significantly higher than those for patients with tumors with low EpCAM expression ( $\mathrm{P}=0.0213)$. Furthermore, the serum EpCAM levels of patients with esophageal cancer were significantly higher than those of normal volunteers $(\mathrm{P}=0.0221)$. The survival rates of patients with a high EpCAM level in the peripheral vein were also significantly higher than those for patients with a low serum EpCAM level $(\mathrm{P}=0.0291)$. The serum EpCAM level in the peripheral vein was independently associated with prognosis $(\mathrm{P}=0.0074$; hazard ratio 7.40$)$. Tumor-specific EpCAM expression and release into the circulation may serve as effective immunotherapy in esophageal cancer patients.
\end{abstract}

\section{Introduction}

EpCAM (also referred to as 17-1A, ESA and EGP40) is a $40-\mathrm{kDa}$ epithelial transmembrane glycoprotein encoded by

Correspondence to: Dr Hitoshi Kimura, Department of General Surgical Science, Gunma University, Graduate School of Medicine, 3-39-22, Showa-machi, Maebashi, Gunma 371-8511, Japan

E-mail: hkimura@med.gunma-u.ac.jp

Key words: EpCAM, real-time RT-PCR, immunohistochemistry, ELISA, prognosis, esophageal cancer the GA733-2 gene, which is located on the long arm of chromosome $4(1,2)$. The EpCAM protein consists of two epidermal growth factor-like extracellular domains, a cysteinepoor region, a transmembrane domain, and a short cytoplasmic tail. The name EpCAM was first suggested by Litvinov et al, to more precisely reflect the function and tissue specificity of the protein $(3,4)$.

EpCAM has a well-known role in $\mathrm{Ca}^{2+}$-independent homophilic cell-cell adhesion,(4) and is also known to be involved in the signaling cascade related to proliferation, differentiation and apoptosis, in addition to other adhesion molecules. In tumor malignancy, EpCAM can be thought of as having a dual role (5). Hence, EpCAM induces dissociation of cadherin-mediated adhesion to promote invasion and metastasis (6-8), but also plays a role as an adhesion molecule that suppresses metastasis by holding cells in place (9). Until recently, the regulation of the EpCAM gene has been unclear, although the promoter region that regulates EpCAM transcription has been cloned and shown to be negatively regulated by TNF- $\alpha$ (10).

EpCAM is strongly expressed in cancers of various origins, including colon and rectum $(11)$, prostate $(12,13)$, liver $(14,15)$, esophagus $(16,17)$, lung $(18,19)$, head and neck $(20)$, and breast (21). Went et al used immunohistochemistry and tissue microarray analysis to detect EpCAM protein expression in various human cancers, and provided a review of EpCAM expression in cancers (22). Furthermore, correlations between EpCAM expression and clinicopathological features have been investigated in various cancers, including breast (23), lung (19), ovary (24), gallbladder (25), kidney (26), and stomach (27). The EpCAM expression level has been shown to be a predictor of survival in cancer patients, but the published results are inconsistent in this respect, and it is possible that EpCAM expression has a bidirectional effect regarding clinicopathological features and prognosis in cancer patients.

EpCAM has become one of the major targets for immunotherapy with monoclonal antibodies because of its specificity in cancerous lesions. For example, postoperative administration of EpCAM-specific murine monoclonal antibody (17-1A) in Dukes' C colorectal cancer patients led to prevention of distant metastasis and to prolonged survival after a 7-year follow-up period (28). Bispecific antibodies against EpCAM and CD3 $(29,30)$ or B7 (31) have been engineered to improve 
cytotoxicity through synergistic effects of antibodies and T-lymphocytes.

We have investigated EpCAM expression in esophageal cancer patients using real-time reverse transcription (RT)-PCR and immunohistochemistry, and determined serum EpCAM levels in these patients using ELISA. Correlations of these data with clinicopathological features of the tumor and prognosis are explored, and we discuss the prospects for EpCAMassociated immunotherapy in esophageal cancer patients.

\section{Materials and methods}

Patients and samples. The study was performed on 138 patients with esophageal cancer who underwent potentially curative surgery without preoperative therapy at the Department of General Surgical Science, Gunma University Graduate School of Medicine, between 1983 and 2004. Tumor stage was classified according to the 6th edition of the tumor-nodemetastasis classification of the International Union Against Cancer (UICC) (32). All patients signed informed consent forms according to our institutional guidelines. Information on gender, age, stage of disease, and histopathologic factors was extracted from medical records.

For preparation of fresh-frozen sections, normal and tumor tissues were collected separately from fresh specimens resected in the operating room. The tissue samples were put into tubes, frozen in liquid nitrogen and stored at $-80^{\circ} \mathrm{C}$ until use. Frozen tumor tissues and corresponding normal tissues from 49 patients were obtained for real-time RT-PCR analysis.

Prior to analysis, the resected specimens were fixed with $10 \%$ formaldehyde, embedded in paraffin blocks, cut into $4-\mu \mathrm{m}$ thick sections, and mounted on glass slides. Paraffinembedded sections were acquired from all 138 patients (121 males and 17 females). The median age of these patients was 62 years, with a range of 40-79 years, and the median survival time was 34.7 months, with a range of 1-211 months.

For ELISA, preoperative serum samples were acquired from 60 patients (54 males and 6 females). The median age of these patients was 62 years, with a range of 41-80 years, and the median survival time was 36.9 months, with a range of 4-68 months. Serum samples from 20 healthy volunteers without any cancer (average age 65.4 years) were assayed as normal controls.

Before surgery, venous blood was obtained from each patient. Blood samples were stored at $4^{\circ} \mathrm{C}$ after collection, and the serum was separated from the blood by centrifugation at $1500 \mathrm{x} \mathrm{g}$ for $5 \mathrm{~min}$. These samples were kept frozen at $-80^{\circ} \mathrm{C}$ without any incident of thawing until they were assayed.

RNA isolation and cDNA synthesis. Total RNA was extracted from fresh-frozen sections using an RNeasy Mini kit (Qiagen, Hilden, Germany) according to the manufacturer's instructions. The quantity of isolated RNA was measured using an ND-1000 spectrophotometer (NanoDrop Technologies, Wilmington, DE). Template cDNA was synthesized from $13.5 \mu \mathrm{g}$ of total RNA with an Omniscript Reverse Transcriptase kit (Qiagen), random primer (hexadeoxyribonucleotide mixture) (Takara, Shiga, Japan) and ribonuclease inhibitor (Porcine liver, Takara).
Total RNA was reverse-transcribed with 4 units of Omniscript reverse transcriptase in a reaction volume of $20 \mu 1$ (60 min at $37^{\circ} \mathrm{C}, 5 \mathrm{~min}$ at $93^{\circ} \mathrm{C}$, and finally on ice). The resultant cDNA samples were stored at $-30^{\circ} \mathrm{C}$ until analysis.

Real-time RT-PCR. Real-time RT-PCR analyses were performed on an ABI Prism 7000 sequence detection system (Applied Biosystems, Foster City, CA) The standard reaction volume was $20 \mu 1$ and contained 1X SYBR Green PCR Master Mix (ABI), $2.0 \mu 1$ of cDNA template, and $1.0 \mu \mathrm{M}$ of both forward and reverse primers. The initial PCR denaturation step was performed for $5 \mathrm{~min}$ at $95^{\circ} \mathrm{C}$, followed by 40 cycles of $60 \mathrm{sec}$ at $95^{\circ} \mathrm{C}$ (melting) and $60 \mathrm{sec}$ at $60^{\circ} \mathrm{C}$ (annealing/ elongation). All reactions were performed in duplicate. The data were normalized to an internal control gene, $B$-actin, to control for the amount of RNA in the preparation. Primers for EpCAM and $B$-actin were used with reference to previously published assays $(33,34)$. The primer sequences were as follows: EpCAM, 5'-CGCAGCTCAGGAAGAATGTG-3' (forward) and 5'-TGAAGTACACTGGCATTGACG-3' (reverse); ß-actin, 5'-CTCCTCCTGAGCGCAAGTACTC-3' (forward) and 5'-TCCTGCTTGCTGATCCACATC-3' (reverse).

Immunohistochemical staining. Immunohistochemical staining of the sections for EpCAM expression was performed by the standard streptavidin-biotin peroxidase complex (S-ABC) method, as described previously $(35,36)$. Each $4-\mu \mathrm{m}$ thick section was deparaffinized, rehydrated and incubated with fresh $0.3 \%$ hydrogen peroxide in methanol for $30 \mathrm{~min}$ at room temperature to block endogenous peroxidase activity. After rehydration through a graded series of ethanol treatments, the sections were autoclaved in $10 \mathrm{mM}$ citrate buffer $(\mathrm{pH} 6.0)$ at $120^{\circ} \mathrm{C}$ for $3 \mathrm{~min}$, and then cooled to $30^{\circ} \mathrm{C}$. After rinsing in $0.1 \mathrm{M}$ phosphate-buffered saline (PBS; $\mathrm{pH} 7.4$ ), non-specific binding sites were blocked by incubation with $10 \%$ normal rabbit serum for $30 \mathrm{~min}$. Sections were incubated with the murine monoclonal antibody KSA (NovoCastra, Medac $\mathrm{GmbH}$, Hamburg, Germany) at a dilution of 1:50 in PBS containing $1 \%$ bovine serum albumin at $4^{\circ} \mathrm{C}$ overnight. The sections were washed in PBS, incubated with biotinylated antimurine $\mathrm{IgG}$ for $30 \mathrm{~min}$ at room temperature, and finally incubated in streptoavidin-biotin peroxidase complex solution (Nichirei Co., Tokyo, Japan). The chromogen, 3,3'-diaminobenzidine tetrahydrochloride, was applied as a $0.02 \%$ solution containing $0.005 \% \mathrm{H}_{2} \mathrm{O}_{2}$ in $50 \mathrm{mM}$ ammonium acetate-citrate acid buffer ( $\mathrm{pH}$ 6.0). The sections were lightly counterstained in Mayer's hematoxylin and mounted. Negative controls were established by replacing the primary antibody with normal rabbit serum, and no detectable staining was evident in these controls.

EpCAM protein expression scoring. EpCAM overexpression was evaluated by calculating the total immunostaining score as the product of the intensity score and the staining rate. The intensity score was based on the estimated staining intensity ( 0 , no staining; 1 , weak; 2 , moderate; 3 , strong), and the staining rate was defined as the percentage of tumor cells with a particular intensity score. Each intensity score (IS: $0,1,2,3)$ was multiplied by its associated staining rate [SR $(\%)$, 


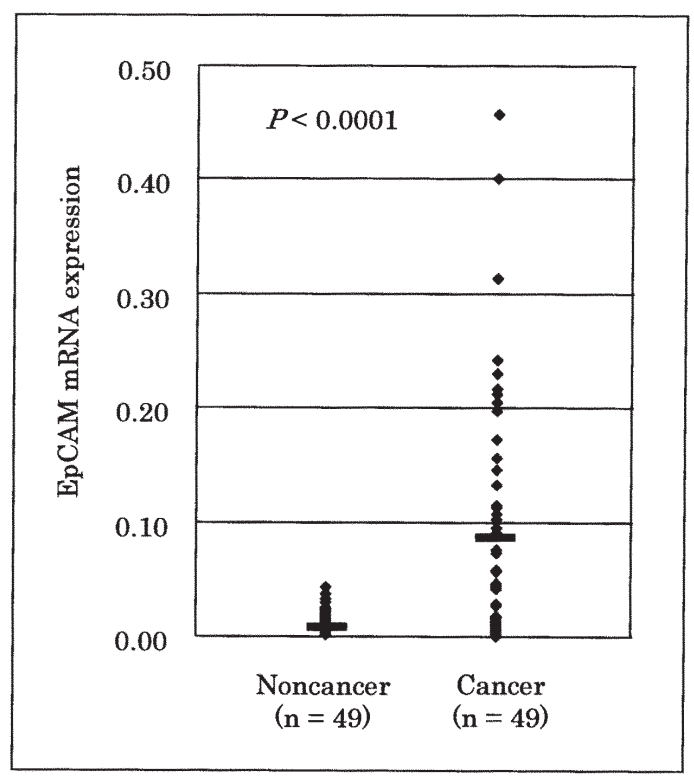

Figure 1. EpCAM mRNA expression in cancerous and non-cancerous esophageal tissues. Horizontal lines indicate means. The cancer tissues showed significantly higher EpCAM mRNA expression levels compared to noncancerous tissues $(\mathrm{P}<0.0001$, Wilcoxon signed-rank test).

and the total immunostaining score was calculated by summing the results over all staining intensities:

$$
\text { total score }=\sum_{\mathrm{n}=0}^{3}(\mathrm{IS} \mathrm{n} \times \mathrm{SR} \mathrm{n} / 100)
$$

Serum EpCAM quantification. Before running the assay, all samples were thawed at $4^{\circ} \mathrm{C}$ overnight and then diluted 1:3 using dilution buffer, based on the instructions in the kit protocol. For quantitative measurements of serum EpCAM levels, a double monoclonal sandwich enzyme immunoassay kit (Human EpCAM ELISA kit, BioVendor Laboratory Medicine, Inc.) was used. All samples were assayed in duplicate in a blinded fashion, and the mean was used for data analysis.

Statistical analysis. Statistical analysis was performed using the Wilcoxon signed-rank test, $\chi^{2}$ test, Mann-Whitney U test, and Kruskal-Wallis test. Survival curves for the patients were calculated using the Kaplan-Meier method, and analysis was performed using the log-rank test. Prognostic factors were examined by univariate and multivariate analyses using a Cox proportional hazards model. $\mathrm{P}<0.05$ was considered significant. All statistical analyses were performed with the SPSS software package (version 13.0, SPSS, Inc., Chicago, IL).

\section{Results}

EpCAM mRNA expression observed by real-time RT-PCR. Analysis of EpCAM mRNA expression in clinical samples showed that 47 of 49 patients $(96 \%)$ had a higher expression level of EpCAM mRNA in cancerous tissues than in noncancerous tissues, based on real-time RT-PCR. The mean expression level of EpCAM mRNA expression in tumor tissues was $0.092 \pm 0.015$ (mean $\pm \mathrm{SEM}$ ), significantly higher than the mean of $0.013 \pm 0.001$ in the corresponding normal tissues $(\mathrm{P}<0.0001$, Fig. 1).
Table I. The correlation between clinicopathological characteristics and EpCAM expression in immunohistochemistry.

\begin{tabular}{|c|c|c|c|c|}
\hline \multirow[b]{2}{*}{ Parameters } & \multirow{2}{*}{$\begin{array}{l}\text { No. of } \\
\text { patients }\end{array}$} & \multicolumn{3}{|c|}{ EpCAM expression } \\
\hline & & High & Low & P-value \\
\hline All patients & 138 & 73 & 65 & \\
\hline $\begin{array}{l}\text { Age (years) } \\
<62 \\
\geq 62\end{array}$ & $\begin{array}{l}63 \\
75\end{array}$ & $\begin{array}{l}32 \\
41\end{array}$ & $\begin{array}{l}31 \\
34\end{array}$ & 0.6498 \\
\hline $\begin{array}{l}\text { Gender } \\
\text { Male } \\
\text { Female }\end{array}$ & $\begin{array}{r}121 \\
17\end{array}$ & $\begin{array}{r}64 \\
9\end{array}$ & $\begin{array}{r}57 \\
8\end{array}$ & 0.9970 \\
\hline $\begin{array}{l}\text { Location } \\
\text { Upper } \\
\text { Midthoracic } \\
\text { Lower }\end{array}$ & $\begin{array}{l}20 \\
84 \\
34\end{array}$ & $\begin{array}{l}13 \\
42 \\
18\end{array}$ & $\begin{array}{r}7 \\
42 \\
16\end{array}$ & 0.4822 \\
\hline $\begin{array}{l}\text { Histological grading } \\
\text { G1 } \\
\text { G2 } \\
\text { G3 } \\
\text { G4 } \\
\text { Unknown }\end{array}$ & $\begin{array}{r}30 \\
69 \\
33 \\
2 \\
4\end{array}$ & $\begin{array}{r}11 \\
42 \\
16 \\
1\end{array}$ & $\begin{array}{r}19 \\
27 \\
17 \\
1\end{array}$ & 0.1600 \\
\hline $\begin{array}{l}\text { Histological type } \\
\text { Squamous cell } \\
\text { carcinoma } \\
\text { Adenocarcinoma } \\
\text { Other types }\end{array}$ & $\begin{array}{r}129 \\
3 \\
6\end{array}$ & $\begin{array}{r}66 \\
3 \\
4\end{array}$ & $\begin{array}{r}63 \\
0 \\
2\end{array}$ & 0.1936 \\
\hline $\begin{array}{l}\text { TNM clinical } \\
\text { classification } \\
\text { T-primary tumor } \\
\text { T1 } \\
\text { T2 } \\
\text { T3 } \\
\text { T4 }\end{array}$ & $\begin{array}{r}62 \\
15 \\
53 \\
8\end{array}$ & $\begin{array}{r}45 \\
6 \\
19 \\
3\end{array}$ & $\begin{array}{r}17 \\
9 \\
34 \\
5\end{array}$ & 0.0005 \\
\hline $\begin{array}{l}\text { N-regional lymph } \\
\text { node metastasis } \\
\text { N0 } \\
\text { N1 }\end{array}$ & $\begin{array}{l}67 \\
71\end{array}$ & $\begin{array}{l}40 \\
33\end{array}$ & $\begin{array}{l}27 \\
38\end{array}$ & 0.1199 \\
\hline $\begin{array}{l}\text { M-distant lymph } \\
\text { node metastasis } \\
\text { M0 } \\
\text { M1 }\end{array}$ & $\begin{array}{r}117 \\
21\end{array}$ & $\begin{array}{l}63 \\
10\end{array}$ & $\begin{array}{l}54 \\
11\end{array}$ & 0.5986 \\
\hline $\begin{array}{l}\text { Stage grouping } \\
\text { I } \\
\text { II } \\
\text { III } \\
\text { IV }\end{array}$ & $\begin{array}{l}47 \\
38 \\
32 \\
21\end{array}$ & $\begin{array}{l}34 \\
19 \\
10 \\
10\end{array}$ & $\begin{array}{l}13 \\
19 \\
22 \\
11\end{array}$ & 0.0037 \\
\hline $\begin{array}{l}\text { Lymphatic invasion } \\
\text { ly }(-) \\
\text { ly }(+)\end{array}$ & $\begin{array}{l}44 \\
94\end{array}$ & $\begin{array}{l}26 \\
47\end{array}$ & $\begin{array}{l}18 \\
47\end{array}$ & 0.3187 \\
\hline $\begin{array}{l}\text { Blood vessel invasion } \\
\text { v (-) } \\
\text { v (+) }\end{array}$ & $\begin{array}{l}68 \\
70\end{array}$ & $\begin{array}{l}42 \\
31\end{array}$ & $\begin{array}{l}26 \\
39\end{array}$ & 0.0397 \\
\hline $\begin{array}{l}\text { Infiltrative growth } \\
\text { pattern } \\
\text { inf } \alpha \\
\text { inf } \beta \\
\text { inf } \gamma\end{array}$ & $\begin{array}{l}36 \\
89 \\
13\end{array}$ & $\begin{array}{r}27 \\
37 \\
9\end{array}$ & $\begin{array}{r}9 \\
52 \\
4\end{array}$ & 0.0015 \\
\hline
\end{tabular}

${ }^{\mathrm{a}} \chi^{2}$ test. 

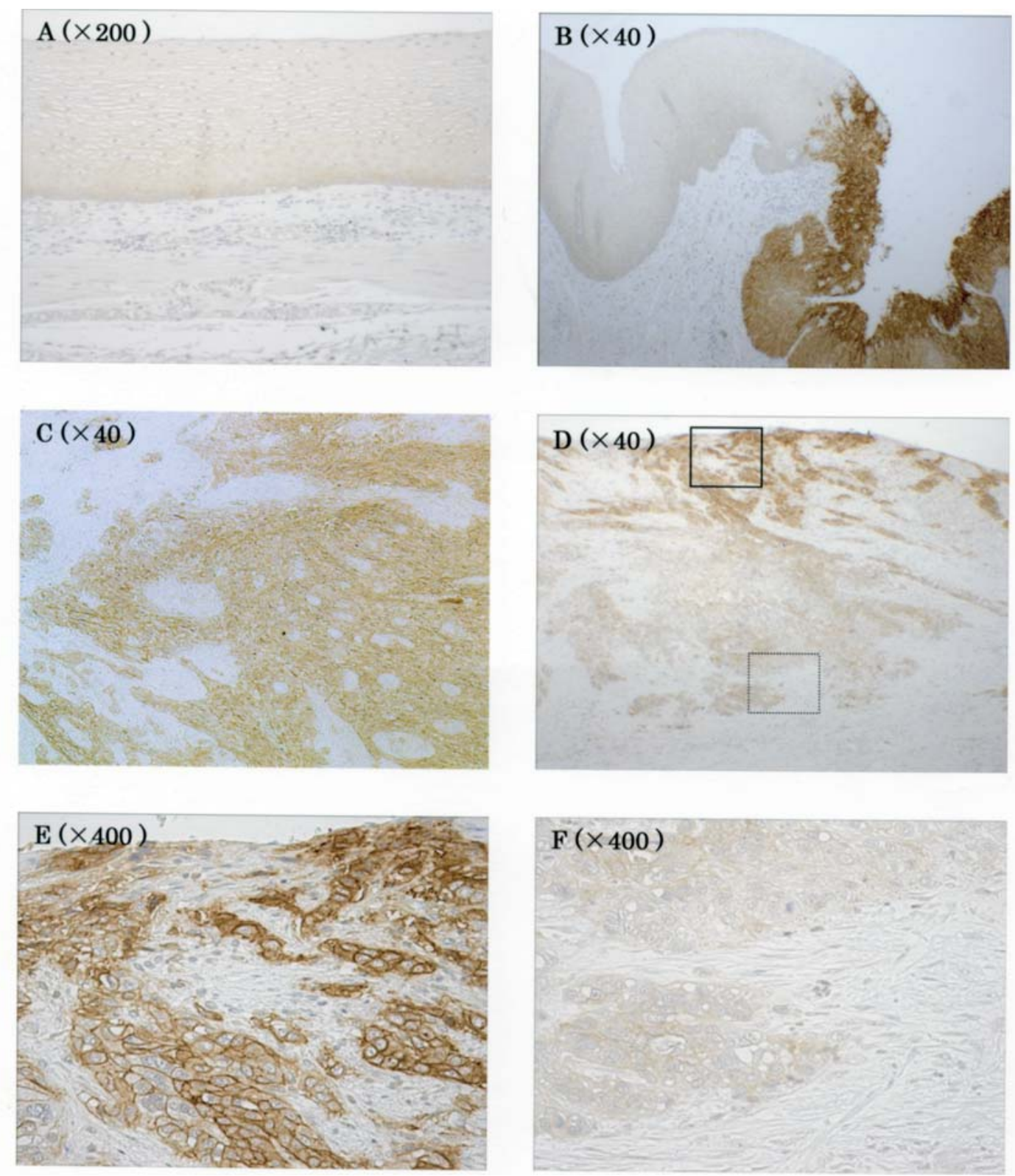

Figure 2. Immunostaining for EpCAM in different tissue sections. (A) Normal esophageal epithelium, in which staining for EpCAM is clearly negative (x200). (B) The border region: EpCAM staining is not detected in the normal esophageal epithelium (left side), whereas strong staining at the plasma membrane is observed in the cancer cells (right side) ( $x 40$ ). (C) Diffuse EpCAM staining in the plasma membrane was identified in advanced cancer tissue ( $x 40)$. (D) Strong expression of EpCAM protein is apparent in shallow areas of the tumor, but expression is reduced in deeper areas of tumor invasion (x40). (E) High-power view of the shallow area enclosed with a full line in D (x400). (F) High-power view of the invasive front enclosed with a dotted line in D $(x 400)$.

Expression of EpCAM protein in esophageal cancer. Staining for EpCAM in the normal esophageal squamous epithelium was clearly negative (Fig. 2A). In cancer cells, EpCAM staining was mainly seen in the plasma membrane, and in border regions only the cancerous lesion stained positive (Fig. 2B). Diffuse staining at the plasma membrane was observed in advanced cancers (Fig. 2C). Some samples showed strong EpCAM expression in shallow areas of the tumor, and reduced expression in deeper areas of the same tumor (Fig. 2D-F). Positive staining for EpCAM was found in $135(97.8 \%)$ of the 138 primary tumor specimens, although heterogeneity was observed in these specimens.

Correlations between EpCAM expression and clinicopathological findings. Patient samples showed a normal distribution of EpCAM expression over different tumor cells. A mean total immunostaining score of $>1.5$ was considered to indicate high EpCAM expression, and based on this criterion 73 of 138 patients showed high EpCAM expression in the tumor and the other 65 patients showed low expression. The correlation between the clinicopathologic characteristics of the esophageal cancer patients and tumor EpCAM expression is summarized in Table I. EpCAM expression was correlated with tumor depth $(\mathrm{P}=0.0005)$, stage $(\mathrm{P}=0.0037)$, blood vessel invasion $(\mathrm{P}=0.0397)$ and infiltrative growth pattern $(\mathrm{P}=0.0015)$. However, there was no significant association between EpCAM expression and other factors, such as age, gender, location, histological grading, histological type, regional lymph node metastasis, distant lymph node metastasis and lymphatic invasion. 


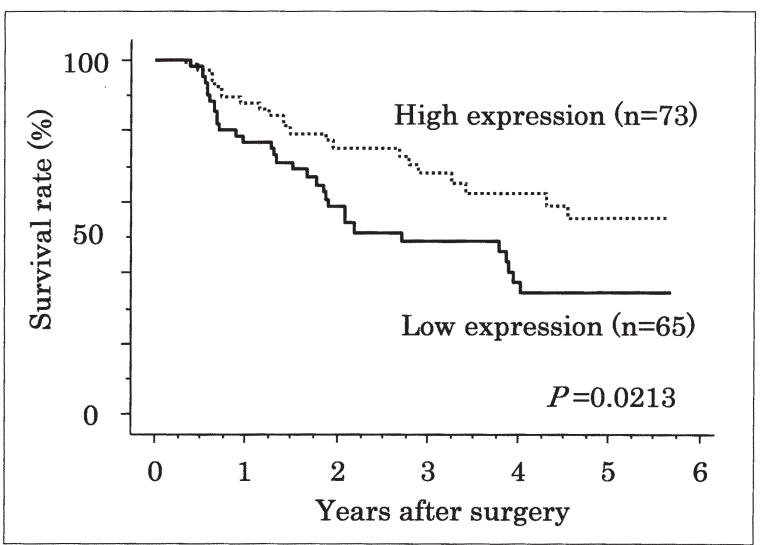

Figure 3. Relationship between overall postoperative survival and EpCAM expression. The survival rates of patients with tumors with high EpCAM expression were significantly higher than those of patients with low EpCAM expression (5-year survival rates: high EpCAM, 55.4\%; low EpCAM, 34.4\%; $\mathrm{P}=0.0213)$.

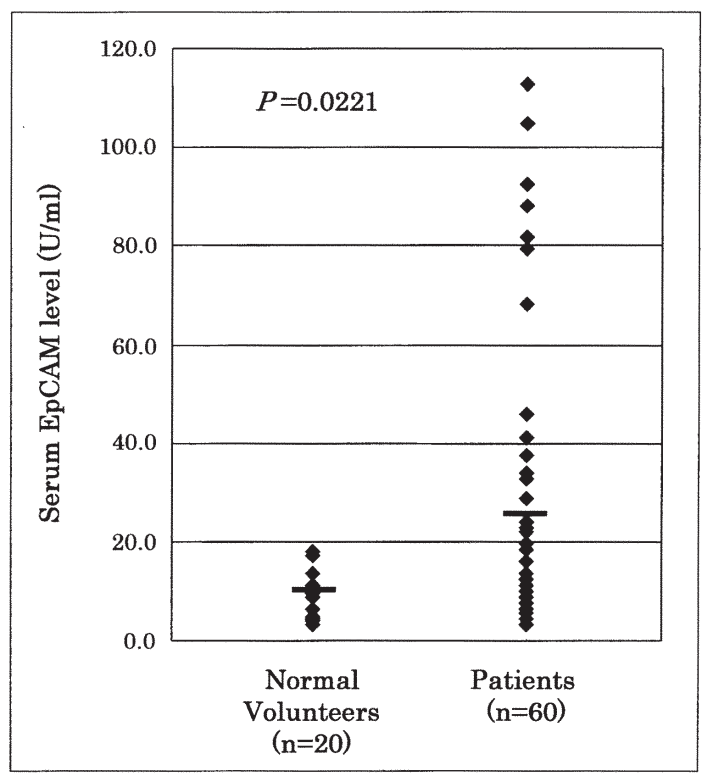

Figure 4. Serum EpCAM levels in normal volunteers and patients with esophageal cancer. Horizontal lines indicate means. The serum EpCAM levels of patients with esophageal cancer were significantly higher than those of normal volunteers $(\mathrm{P}=0.0221$, Mann-Whitney $\mathrm{U}$ test).

Prognostic significance of EpCAM expression. The survival rates of patients with tumors showing high EpCAM expression was significantly higher than those of patients with tumors showing low EpCAM expression ( $\mathrm{P}=0.0213$; Fig. 3 ). The 5-year survival rate of patients with high EpCAM expression was significantly higher than that of patients with low EpCAM expression (55.4\% vs. 34.4\%). However, the tumor EpCAM expression in esophageal cancer patients was not identified as an independent prognostic factor in a multivariate survival analysis using a Cox proportional hazards model (data not shown).

Serum EpCAM levels in patients with esophageal cancer. The preoperative serum EpCAM levels were 23.7 $\pm 3.5 \mathrm{U} / \mathrm{ml}$ $($ mean \pm SEM) in patients with esophageal cancer and
Table II. The correlation between clinicopathological characteristics and serum EpCAM level.

\begin{tabular}{|c|c|c|c|}
\hline Parameters & $\begin{array}{l}\text { No. of } \\
\text { patients }\end{array}$ & $\begin{array}{c}\text { S-EpCAM } \\
\left(\text { mean } \pm \mathrm{SEM}^{\mathrm{a}}\right) \\
\mathrm{U} / \mathrm{ml}\end{array}$ & P-value \\
\hline
\end{tabular}

\begin{tabular}{lrr}
\hline Age (years) & & \\
$<62$ & 27 & $26.8 \pm 5.65$ \\
$\geq 62$ & 33 & $21.2 \pm 4.53$ \\
Gender & & \\
$\quad$ Male & 54 & $24.4 \pm 3.89$ \\
Female & 6 & $1.80 \pm 5.73$ \\
Location & & \\
$\quad$ Upper & 8 & $17.2 \pm 5.75$ \\
Midthoracic & 35 & $29.0 \pm 5.18$ \\
Lower & 17 & $14.9 \pm 4.79$ \\
Histological grading & & \\
G1 & 15 & $10.4 \pm 2.10$ \\
G2 & 26 & $31.8 \pm 6.95$ \\
G3 & 15 & $22.6 \pm 6.10$ \\
G4 & 2 & $27.1 \pm 5.39$
\end{tabular}

$0.2588^{\mathrm{b}}$

$0.9411^{\mathrm{b}}$

$0.0803^{c}$

$0.0931^{\mathrm{c}}$

Unknown

$0.2757^{c}$

Stype

Squamous cell

carcinoma

Adenocarcinoma

Other types

$24.8 \pm 4.04$

$11.2 \pm 3.64$

$26.1 \pm 3.28$

TNM clinical

classification

T-primary tumor

T1

$23.3 \pm 5.76$

$0.0614^{c}$

$\mathrm{T} 2$

T3

T4

$5.67 \pm 1.21$

$24.5 \pm 4.77$

$42.5 \pm 24.0$

$\mathrm{N}$-regional lymph

node metastasis

NO

$25.9 \pm 5.61$

$\mathrm{N} 1$

$22.1 \pm 4.61$

M-distant lymph

node metastasis

M0

$24.0 \pm 3.94$

M1

$22.3 \pm 8.34$

Stage grouping

I

II

III

$20.8+4.95$

$24.0 \pm 8.16$

$26.7 \pm 7.37$

$22.3 \pm 8.34$

Lymphatic invasion

$21.5 \pm 5.30$

ly (-)

ly (+)

$24.3 \pm 4.25$

$0.6243^{\mathrm{b}}$

Blood vessel

invasion

$\begin{array}{lll}\mathrm{v}(-) & 17 & 22.6 \pm 6.50 \\ \mathrm{v}(+) & 43 & 24.1 \pm 4.28\end{array}$

$0.9477^{\mathrm{b}}$

$\mathrm{V}(+)$

$24.1 \pm 4.28$

Infiltrative growth

pattern

$\begin{array}{lrr}\inf \alpha & 8 & 27.1 \pm 13.5 \\ \inf \beta & 43 & 24.4 \pm 4.04 \\ \inf \gamma & 9 & 17.6 \pm 7.92\end{array}$

$0.4358^{c}$

${ }^{a}$ SEM, standard error of mean; ${ }^{b}$ Mann-Whitney's U test; ${ }^{c}$ KruskalWallis test. 
Table III. Cox proportional hazards analysis.

\begin{tabular}{|c|c|c|c|c|}
\hline Risk factor & Reference factor & P-value & Hazard ratio & $95 \% \mathrm{CI}$ \\
\hline \multicolumn{5}{|l|}{ Univariate } \\
\hline Histological grading & G1, G2, vs. G3, G4 & 0.0229 & 2.61 & $1.14-5.97$ \\
\hline Primary tumor $(\mathrm{T})$ & $\mathrm{T} 1$ vs. T2, T3, T4 & 0.0078 & 5.26 & $1.55-17-9$ \\
\hline Regional lymph node metastasis $(\mathrm{N})$ & Negative vs. positive & 0.0006 & 8.97 & $2.57-31.3$ \\
\hline Distant lymph node metastasis (M) & Negative vs. positive & 0.0345 & 2.78 & $1.08-7.17$ \\
\hline Serum EpCAM level & High vs. low & 0.0370 & 2.88 & $1.07-7.79$ \\
\hline \multicolumn{5}{|l|}{ Multivariate } \\
\hline Histological grading & G1, G2, vs. G3, G4 & 0.0231 & 3.03 & $1.17-7.89$ \\
\hline Primary tumor $(\mathrm{T})$ & $\mathrm{T} 1$ vs. T2, T3, T4 & 0.2051 & 2.35 & $0.63-8.85$ \\
\hline Regional lymph node metastasis $(\mathrm{N})$ & Negative vs. positive & 0.0069 & 6.39 & $1.66-24.6$ \\
\hline Distant lymph node metastasis (M) & Negative vs. positive & 0.3989 & 1.56 & $0.56-4.36$ \\
\hline Serum EpCAM level & High vs. low & 0.0074 & 4.30 & $1.48-12.5$ \\
\hline
\end{tabular}

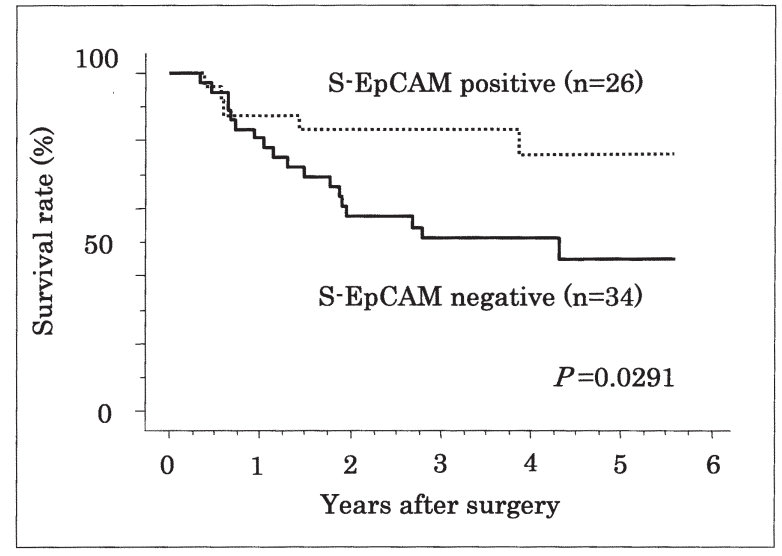

Figure 5. Relationship between overall postoperative survival and serum EpCAM level. The survival rates of patients with high serum EpCAM levels were significantly higher than those of patients with low serum EpCAM levels (5-year survival rates: high EpCAM, 75.8\%; low EpCAM, 44.5\%; $\mathrm{P}=0.0291)$.

$9.3 \pm 1.1 \mathrm{U} / \mathrm{ml}$ in normal volunteers; these levels differed significantly ( $\mathrm{P}=0.0221$; Fig. 4). No significant correlation was found between the clinicopathologic characteristics of esophageal cancer patients and serum EpCAM levels in peripheral veins (Table II).

Prognostic significance of serum EpCAM levels. We determined the cutoff value as $13.5 \mathrm{U} / \mathrm{ml}$, which was the median EpCAM level measured from peripheral veins of esophageal cancer patients, to assess the prognostic value of the serum EpCAM level in the peripheral veins. Based on a cutoff value of $13.5 \mathrm{U} / \mathrm{ml}$, patients with esophageal cancer were categorized into two groups: the high serum EpCAM group $(n=26)$ and the low serum EpCAM group $(n=34)$. There were no significant differences in age and sex between these groups. The survival rates of patients with high EpCAM levels in the peripheral vein were significantly higher than those of patients with low serum EpCAM levels ( $\mathrm{P}=0.0291)$ (Fig. 5).
The 5-year survival rate of patients with high EpCAM levels in the peripheral vein was $75.8 \%$, and that of patients with low serum EpCAM levels was $44.5 \%$. Moreover, to clarify whether the serum EpCAM level is a significant prognostic marker, univariate and multivariate survival analyses were performed using a Cox proportional hazards model. These analyses showed that the serum EpCAM level in the peripheral vein is an independent prognostic factor $(\mathrm{P}=0.0074$; hazard ratio 4.30) (Table III).

\section{Discussion}

In this study, we investigated the serum EpCAM level and the expression levels of EpCAM mRNA and protein in clinical samples from esophageal cancer patients. EpCAM mRNA expression was significantly increased in tumor tissues compared with normal tissues, EpCAM protein was positively expressed in $97.8 \%$ of esophageal cancer patients, and the EpCAM protein level was significantly correlated with tumor invasion, stage grouping, blood vessel invasion and infiltrative growth pattern. Furthermore, the serum EpCAM levels of patients with esophageal cancer were significantly higher than those of normal volunteers, and the serum EpCAM level in the peripheral vein was identified as an independent prognostic factor in esophageal cancer patients.

Expression of EpCAM is found in cancerous lesions in the early phase of carcinogenesis in esophageal cancer patients, and is inversely correlated with tumor progression in these patients. Therefore, it is thought that EpCAM acts as a tumor-specific antigen that stimulates an immunological response, as well as playing a role as an adhesion molecule that suppresses metastasis. These functions may have an effect on prognosis in esophageal cancer patients. Furthermore, a high serum EpCAM level may cause a stronger immunological response against the tumor, and this may account for the identification of the serum EpCAM level as an independent prognostic factor.

EpCAM has been found to be strongly expressed in cancers of various origins $(22,37)$. The expression of EpCAM 
in cancerous tissues was anticipated based on pathological studies, and this has recently been confirmed at the mRNA level. Hence, Osta et al showed that EpCAM mRNA is significantly overexpressed in primary and metastatic breast cancer tissues (33), and Mitas et al reported that EpCAM is useful for discriminating normal esophageal tissue from esophageal adenocarcinoma tissue using real-time RT-PCR (38).

The normal squamous epithelium of the esophagus is clearly negative for EpCAM, while the columnar epithelium in Barrett's esophagus displays a diffuse and low EpCAM expression pattern (39). The expression of EpCAM in esophageal cancer has been reported in preliminary data from Kumble et al with high EpCAM expression levels found in four tested adenocarcinomas of the esophagus (16), and Went et al reported that 38 of 43 patients (88.4\%) with esophageal cancer were EpCAM-positive (22). Our study is the first to suggest a correlation between EpCAM expression and clinicopathological features in esophageal cancer based on a large number of surgical specimens. Correlations between EpCAM expression and clinicopathological features have been reported for cancers of other origins; the expression of EpCAM is correlated with malignant progression of lung cancer (19), breast cancer (23), and gallbladder cancer (25), whereas the EpCAM level has been correlated with suppression of malignancy in ovarian cancer (24), renal cell carcinoma (26) and gastric cancer (27). Hence, the correlation between EpCAM expression and tumor prognosis appears to be bilateral; our data are consistent with the latter investigations showing a correlation with suppression of malignancy.

Our immunohistochemical investigation showed that several patients lost expression of EpCAM at the invasive front. Similar phenomena associated with adhesion molecules have also been observed in previous studies. For example, metastasis of oral squamous cell carcinoma was shown to correlate with a reduction in immunohistochemical staining for desmoplakin and desmoglein at the invasive front $(40,41)$. Furthermore, in oral squamous cell carcinoma, a tendency for reduction of E-cadherin staining at the invasive front has been found, and this reduction was correlated with the mode of invasion (42). In a model system, Basak et al showed that EpCAM-mediated adhesion can suppress invasion of tumor-cell grafts in mice (9), and therefore it is plausible that EpCAM-negative cells reduce cell-cell adhesion, thereby promoting invasion and metastasis.

Abe et al reported increased EpCAM levels in the serum of approximately $10 \%$ of patients with malignant tumors of various tissue origins, suggesting that EpCAM is released from tumor cells into the circulation under certain conditions (43). In our study, the survival rates of patients with high serum EpCAM levels were significantly higher than those of patients with low serum EpCAM levels, and the serum EpCAM level in the peripheral vein was an independent prognostic factor. A high EpCAM level may contribute to a good prognosis in esophageal cancer patients through suppression of malignancy. The levels of other adhesion molecules, such as E-cadherin $(44,45)$ and ICAM-1 (46) have been investigated in several cancers: among patients with advanced ovarian carcinoma, preoperative serum Ecadherin was not correlated with common clinicopathological prognostic variables or with response to chemotherapy and survival (45), and serum ICAM-1 levels did not correlate with malignancy in patients with non-small cell lung carcinoma (46). Furthermore, although a sequential analysis showed that rising serum ICAM-1 levels predicted a short-term fatal outcome, overall serum ICAM-1 levels did not correlate with prognosis (46). Hence, it seems that the level of adhesion molecules in serum does not always reflect the extent of malignant progression.

In contrast to the lack of correlation of the levels of certain adhesion molecules with malignancy, we propose the hypothesis that EpCAM released into the circulation functions as an immunogenic agent and activates an immunologic response against EpCAM-positive tumors. This hypothesis is supported by the recent identification of EpCAM-derived peptides that elicit cellular immune responses restricted by HLA*0201 $(47,48)$, and it is of note that a natural T-cell response against EpCAM has been observed in colorectal cancer patients $(49,50)$. Tajima et al reported an epitope from EpCAM that elicited HLA-A*2402-restricted cytotoxic Tlymphocyte responses and investigated the possibility of immunotherapy using the corresponding T-lymphocytes (51). Hence, administration of recombinant EpCAM and induction of cytotoxic T-lymphocyte responses against EpCAM-positive tumors may be useful as a therapy for esophageal cancer. In addition to the potential of EpCAM in targeted immunotherapy, our data show that the serum EpCAM level in the peripheral vein is an independent prognostic factor for survival of patients with esophageal cancer.

\section{Acknowledgements}

We thank R. Aoyagi for excellent technical assistance, S. Ueno, A. Nakabayashi, T. Ogasawara, H. Emura and Y. Saitoh for their excellent secretarial help, and M. Ohno for her assistance with data management and biostatistical analysis.

\section{References}

1. Gottlinger HG, Funke I, Johnson JP, Gokel JM and Riethmuller G: The epithelial cell surface antigen 17-1A, a target for antibodymediated tumor therapy: its biochemical nature, tissue distribution and recognition by different monoclonal antibodies. Int J Cancer 38: 47-53, 1986 .

2. Linnenbach AJ, Wojcierowski J, Wu SA, Pyrc JJ, Ross AH, Dietzschold B, Speicher D and Koprowski H: Sequence investigation of the major gastrointestinal tumor-associated antigen gene family, GA733. Proc Natl Acad Sci USA 86: 27-31, 1989.

3. Litvinov SV, van Driel W, van Rhijn CM, Bakker HA, van Krieken H, Fleuren GJ and Warnaar SO: Expression of Ep-CAM in cervical squamous epithelia correlates with an increased proliferation and the disappearance of markers for terminal differentiation. Am J Pathol 148: 865-875, 1996.

4. Litvinov SV, Velders MP, Bakker HA, Fleuren GJ and Warnaar SO: Ep-CAM: a human epithelial antigen is a homophilic cell-cell adhesion molecule. J Cell Biol 125: 437-446, 1994.

5. Balzar M, Prins FA, Bakker HA, Fleuren GJ, Warnaar SO and Litvinov SV: The structural analysis of adhesions mediated by Ep-CAM. Exp Cell Res 246: 108-121, 1999.

6. Gumbiner BM: Cell adhesion: the molecular basis of tissue architecture and morphogenesis. Cell 84: 345-357, 1996.

7. Litvinov SV, Balzar M, Winter MJ, Bakker HA, Briaire-de Bruijn IH, Prins F, Fleuren GJ and Warnaar SO: Epithelial cell adhesion molecule (Ep-CAM) modulates cell-cell interactions mediated by classic cadherins. J Cell Biol 139: 1337-1348, 1997. 
8. Balzar M, Winter MJ, De Boer CJ and Litvinov SV: The biology of the 17-1A antigen (Ep-CAM). J Mol Med 77: 699$712,1999$.

9. Basak S, Speicher D, Eck S, Wunner W, Maul G, Simmons MS and Herlyn D: Colorectal carcinoma invasion inhibition by CO17-1A/GA733 antigen and its murine homologue. J Natl Cancer Inst 90: 691-697, 1998.

10. Gires O, Kieu C, Fix P, Schmitt B, Munz M, Wollenberg B and Zeidler R: Tumor necrosis factor alpha negatively regulates the expression of the carcinoma-associated antigen epithelial cell adhesion molecule. Cancer 92: 620-628, 2001.

11. Herlyn M, Steplewski Z, Herlyn D and Koprowski H: Colorectal carcinoma-specific antigen: detection by means of monoclonal antibodies. Proc Natl Acad Sci USA 76: 1438-1442, 1979.

12. Zhang S, Zhang HS, Reuter VE, Slovin SF, Scher HI and Livingston PO: Expression of potential target antigens for immunotherapy on primary and metastatic prostate cancers. Clin Cancer Res 4: 295-302, 1998.

13. Poczatek RB, Myers RB, Manne U, Oelschlager DK, Weiss HL, Bostwick DG and Grizzle WE: Ep-Cam levels in prostatic adenocarcinoma and prostatic intraepithelial neoplasia. J Urol 162: 1462-1466, 1999.

14. de Boer CJ, van Krieken JH, Janssen-van Rhijn CM and Litvinov SV: Expression of Ep-CAM in normal, regenerating, metaplastic, and neoplastic liver. J Pathol 188: 201-206, 1999.

15. Ruck P, Wichert G, Handgretinger R and Kaiserling E: Ep-CAM in malignant liver tumours. J Pathol 191: 102-103, 2000.

16. Kumble S, Omary MB, Fajard, LF and Triadafilopoulos G: Multifocal heterogeneity in villin and Ep-CAM expression in Barrett's esophagus. Int J Cancer 66: 48-54, 1996.

17. Martin IG, Cutts SG, Birbeck K, Gray S and Quirke P: Expression of the 17-1A antigen in gastric and gastro-oesophageal junction adenocarcinomas: a potential immunotherapeutic target? J Clin Pathol 52: 701-704, 1999.

18. Kubuschok B, Passlick B, Izbicki JR, Thetter O and Pantel K: Disseminated tumor cells in lymph nodes as a determinant for survival in surgically resected non-small cell lung cancer. J Clin Oncol 17: 19-24, 1999.

19. Piyathilake CJ, Frost AR, Weiss H, Manne U, Heimburger DC and Grizzle WE: The expression of Ep-CAM (17-1A) in squamous cell cancers of the lung. Hum Pathol 31: 482-487, 2000.

20. Takes RP, Baatenburg de Jong RJ, Schuuring E, Hermans J, Vis AA, Litvinov SV and van Krieken JH: Markers for assessment of nodal metastasis in laryngeal carcinoma. Arch Otolaryngol Head Neck Surg 123: 412-419, 1997.

21. Edwards DP, Grzyb KT, Dressler LG, Mansel RE, Zava DT, Sledge GW Jr and McGuire WL: Monoclonal antibody identification and characterization of a $\mathrm{Mr}$ 43,000 membrane glycoprotein associated with human breast cancer. Cancer Res 46: 1306-1317, 1986

22. Went PT, Lugli A, Meier S, Bundi M, Mirlacher M, Sauter G and Dirnhofer S: Frequent EpCam protein expression in human carcinomas. Hum Pathol 35: 122-128, 2004.

23. Gastl G, Spizzo G, Obrist P, Dunser M and Mikuz G: Ep-CAM overexpression in breast cancer as a predictor of survival. Lancet 356: 1981-1982, 2000.

24. Kim JH, Herlyn D, Wong KK, Park DC, Schorge JO, Lu KH, Skates SJ, Cramer DW, Berkowitz RS and Mok SC: Identification of epithelial cell adhesion molecule autoantibody in patients with ovarian cancer. Clin Cancer Res 9: 4782-4791, 2003.

25. Varga M, Obrist P, Schneeberger S, Muhlmann G, FelgelFarnholz C, Fong D, Zitt M, Brunhuber T, Schafer G, Gastl G and Spizzo G: Overexpression of epithelial cell adhesion molecule antigen in gallbladder carcinoma is an independent marker for poor survival. Clin Cancer Res 10: 3131-3136, 2004.

26. Seligson DB, Pantuck AJ, Liu X, Huang Y, Horvath S, Bui MH, Han KR, Correa AJ, Eeva M, Tze S, Belldegrun AS and Figlin RA: Epithelial cell adhesion molecule (KSA) expression: pathobiology and its role as an independent predictor of survival in renal cell carcinoma. Clin Cancer Res 10: 2659-2669, 2004.

27. Songun I, Litvinov SV, van de Velde CJ, Pals ST, Hermans J and van Krieken JH: Loss of Ep-CAM (CO17-1A) expression predicts survival in patients with gastric cancer. Br J Cancer 92: 1767-1772, 2005
28. Riethmuller G, Holz E, Schlimok G, Schmiegel W, Raab R, Hoffken K, Gruber R, Funke I, Pichlmaier H, Hirche H, Buggisch P, Witte J and Pichlmayr R: Monoclonal antibody therapy for resected Dukes' C colorectal cancer: 7-year outcome of a multicenter randomized trial. J Clin Oncol 16: 1788-1794, 1998.

29. Wimberger P, Xiang W, Mayr D, Diebold J, Dreier T, Baeuerle PA and Kimmig R: Efficient tumor cell lysis by autologous, tumorresident $\mathrm{T}$ lymphocytes in primary ovarian cancer samples by an EP-CAM-/CD3-bispecific antibody. Int J Cancer 105: 241-248, 2003.

30. Maletz K, Kufer P, Mack M, Raum T, Pantel K, Riethmuller G and Gruber R: Bispecific single-chain antibodies as effective tools for eliminating epithelial cancer cells from human stem cell preparations by redirected cell cytotoxicity. Int J Cancer 93: 409-416, 2001

31. Kufer P, Zettl F, Borschert K, Lutterbuse R, Kischel R and Riethmuller G: Minimal costimulatory requirements for $\mathrm{T}$ cell priming and TH1 differentiation: activation of naive human $\mathrm{T}$ lymphocytes by tumor cells armed with bifunctional antibody constructs. Cancer Immun 1: 10, 2001

32. Sobin LH and Witteking CH (eds): TNM Classificaton of Malignant Tumours. 6th edition. John Wiley \& Sons, Inc., New York, 2002.

33. Osta WA, Chen Y, Mikhitarian K, Mitas M, Salem M, Hannun YA, Cole DJ and Gillanders WE: EpCAM is overexpressed in breast cancer and is a potential target for breast cancer gene therapy. Cancer Res 64: 5818-5824, 2004.

34. Furuya M, Nishiyama M, Kimura S, Suyama T, Naya Y, Ito H, Nikaido $\mathrm{T}$ and Ishikura $\mathrm{H}$ : Expression of regulator of $\mathrm{G}$ protein signalling protein 5 (RGS5) in the tumour vasculature of human renal cell carcinoma. J Pathol 203: 551-558, 2004.

35. Kato H, Yoshikawa M, Miyazaki T, Nakajima M, Fukai Y, Masuda N, Fukuchi M, Manda R, Tsukada K and Kuwano H: Expression of vascular endothelial growth factor (VEGF) and its receptors (Flt-1 and Flk-1) in esophageal squamous cell carcinoma. Anticancer Res 22: 3977-3984, 2002.

36. Fukai Y, Masuda N, Kato H, Fukuchi M, Miyazaki T, Nakajima M, Sohda M, Kuwano H and Nakajima T: Correlation between laminin-5 gamma2 chain and epidermal growth factor receptor expression in esophageal squamous cell carcinomas. Oncology 69: 71-80, 2005

37. Winter MJ, Nagelkerken B, Mertens AE, Rees-Bakker HA, Briaire-de Bruijn IH and Litvinov SV: Expression of Ep-CAM shifts the state of cadherin-mediated adhesions from strong to weak. Exp Cell Res 285: 50-58, 2003.

38. Mitas M, Almeida JS, Mikhitarian K, Gillanders WE, Lewin DN, Spyropoulos DD, Hoover L, Graham A, Glenn T, King P, Cole DJ, Hawes R, Reed CE and Hoffman BJ: Accurate discrimination of Barrett's esophagus and esophageal adenocarcinoma using a quantitative three-tiered algorithm and multimarker real-time reverse transcription-PCR. Clin Cancer Res 11: 2205-2214, 2005.

39. Momburg F, Moldenhauer G, Hammerling GJ and Moller P: Immunohistochemical study of the expression of a Mr 34,000 human epithelium-specific surface glycoprotein in normal and malignant tissues. Cancer Res 47: 2883-2891, 1987.

40. Harada T, Shinohara M, Nakamura S, Shimada M and Oka M: Immunohistochemical detection of desmosomes in oral squamous cell carcinomas: correlation with differentiation, mode of invasion, and metastatic potential. Int J Oral Maxillofac Surg 21: 346-349, 1992

41. Hiraki A, Shinohara M, Ikebe T, Nakamura S, Kurahara S and Garrod DR: Immunohistochemical staining of desmosomal components in oral squamous cell carcinomas and its association with tumour behaviour. Br J Cancer 73: 1491-1497, 1996.

42. Shinohara M, Hiraki A, Ikebe T, Nakamura S, Kurahara S, Shirasuna K and Garrod DR: Immunohistochemical study of desmosomes in oral squamous cell carcinoma: correlation with cytokeratin and E-cadherin staining, and with tumour behaviour. J Pathol 184: 369-381, 1998.

43. Abe $\mathrm{H}$, Kuroki $\mathrm{M}$, Imakiire $\mathrm{T}$, Yamauchi $\mathrm{Y}$, Yamada $H$, Arakawa F and Kuroki M: Preparation of recombinant MK-1/ Ep-CAM and establishment of an ELISA system for determining soluble MK-1/Ep-CAM levels in sera of cancer patients. J Immunol Methods 270: 227-233, 2002.

44. Katayama M, Hirai S, Kamihagi K, Nakagawa K, Yasumoto M and Kato I: Soluble E-cadherin fragments increased in circulation of cancer patients. Br J Cancer 69: 580-585, 1994. 
45. Gadducci A, Ferdeghini M, Cosio S, Annicchiarico C, Ciampi B, Bianchi R and Genazzani AR: Preoperative serum E-cadherin assay in patients with ovarian carcinoma. Anticancer Res 19: 769-772, 1999.

46. Grothey A, Heistermann P, Philippou S and Voigtmann R: Serum levels of soluble intercellular adhesion molecule-1 (ICAM-1, CD54) in patients with non-small cell lung cancer: correlation with histological expression of ICAM-1 and tumour stage. Br J Cancer 77: 801-807, 1998.

47. Trojan A, Witzens M, Schultze JL, Vonderheide RH, Harig S, Krackhardt AM, Stahel RA and Gribben JG: Generation of cytotoxic $\mathrm{T}$ lymphocytes against native and altered peptides of human leukocyte antigen- $A * 0201$ restricted epitopes from the human epithelial cell adhesion molecule. Cancer Res 61: 4761-4765, 2001.

48. Jager E, Ringhoffer M, Altmannsberger M, Arand M, Karbach J, Jager D, Oesch $\mathrm{F}$ and Knuth A: Immunoselection in vivo: independent loss of MHC class I and melanocyte differentiation antigen expression in metastatic melanoma. Int J Cancer 71: 142-147, 1997.
49. Nagorsen D, Scheibenbogen C, Marincola FM, Letsch A and Keilholz U: Natural T cell immunity against cancer. Clin Cancer Res 9: 4296-4303, 2003.

50. Nagorsen D, Keilholz U, Rivoltini L, Schmittel A, Letsch A, Asemissen AM, Berger G, Buhr HJ, Thiel E and Scheibenbogen C: Natural T-cell response against MHC class I epitopes of epithelial cell adhesion molecule, her- $2 /$ neu, and carcinoembryonic antigen in patients with colorectal cancer. Cancer Res 60: 4850-4854, 2000.

51. Tajima K, Demachi A, Ito Y, Nishida K, Akatsuka Y, Tsujimura K, Kuwano H, Mitsudomi T, Takahashi T and Kuzushima K: Identification of an epitope from the epithelial cell adhesion molecule eliciting HLA-A*2402-restricted cytotoxic T-lymphocyte responses. Tissue Antigens 64: 650-659, 2004. 